\title{
Strategi Digital Marketing PT. Indosat Ooredoo Medan Dalam Meningkatkan Kepercayaan Pelanggan
}

\author{
Yudi Hamdani \\ Universitas Muhammadiyah Sumatera Utara \\ e-mail: yudihamdani@gmail.com
}

\begin{abstract}
For the digital marketing is very important not only in terms of trade with, in it but information and social development is felt its impact for users of social media.So the digital world demanded the entire community to get access, consume digital technology to be kept abreast of developments and information. socialOne of the ads also post, ooredoo indosat which confers prizes, quiz a race, creativity that is competition and competition. social mediaAs a form of services available to the community to actively participate in paying attention to the social media program made by indosat ooredoo. It is called research pt marketing digital strategy.Indosat ooredoo a in increase the confidence of customers.Results is getting good, seen from several the interviews done that very influential digital marketing on the trust of customers because if it is seen post attractive, competitions which confers prizes, so the customers have more confidence in indosat. Facilities indosat application myim 3 also the most helpful and ease to access packages offered.Nelfon and internet facilities provided indosat also needs a days has helped in the communication.
\end{abstract}

Key Word: Digital strategy, Marketing, Customers

\begin{abstract}
Abstrak
Digital marketing sangatlah penting bagi masyarakat tidak hanya ditinjau dari sisi jual beli di dalamnya, tetapi informasi dan perkembangan sosial sangat dirasakan dampaknya bagi pengguna sosial media. Sehingga dunia digital menuntut seluruh masyarakat untuk dapat mengakses, mengkonsumsi teknologi digital agar dapat terus mengikuti perkembangan sosial dan informasi. Salah satu program Indosat Ooredoo juga memposting iklan, kuis berhadiah, perlombaan kreatifitas, dan kompetisi - kompetisi yang bersifat media sosial. Sebagai bentuk pelayanan bagi masyarakat yang terus ikut aktif dalam memperhatikan programprogram media sosial yang dibuat oleh Indosat Ooredoo. Penelitian ini berjudul strategi digital marketing PT. Indosat Ooredoo Medan dalam meningkatkan kepercayaan pelanggan. Hasil penelitian ini sudah terbilang baik, dilihat dari beberapa pandangan hasil wawancara yang dilakukan bahwa digital marketing sangat berpengaruh pada kepercayaan pelanggan karena dilihat dari postingan yang menarik, kompetisi-kompetisi berhadiah, sehingga para pelanggan menaruh kepercayaan pada Indosat. Fasilitas aplikasi Indosat yaitu myim3 juga sangat membantu dan mempermudah dalam mengakses paket-paket yang ditawarkan.
\end{abstract}


Fasilitas nelfon dan internet yang disediakan Indosat juga sangat membantu dalam kebutuhan komunikasi sehari-hari.

Kata kunci : Strategi, Digital marketing, pelanggan.

\section{Latar Belakang Masalah}

Digital marketing telah menjadi sangat penting dalam kehidupan manusia terutama dengan mudahnya teknologi dengan mobilitas serta gadget yang semakin terjangkau oleh semua kalangan. Mulai dari sosial media hingga teknik yang lebih canggih seperti Facebook, Twitter, Linkedin, Intagram dan lain sebagainya. Informasi pun sangat cepat diterima dan dibagikan oleh semua orang dan dapat di akses serta dicerna oleh siapa saja yang mempunyai akses ke Internet (Susanto J dan Rovelim 2016).

Sanjaya \& Tarigan (2013) Digital marketing adalah kegiatan marketing termasuk branding yang menggunakan berbagai media berbasis web seperti blog,web site,email, adwords, ataupun jejaring sosial. Tentu saja digital marketing bukan hanya berbicara tentang marketing internet. Jadi mengapa para marketer di seluruh Asia tidak mengalihkan penggunaan budget dari marketing tradisional seperti TV, radio, dan media cetak ke arah media teknologi baru dan media yang lebih interaktif

Dalam hal ini digital marketing sangatlah penting bagi masyarakat tidak hanya ditinjau dari sisi jual beli di dalamnya, tetapi informasi dan perkembangan sosial sangat dirasakan dampaknya bagi pengguna sosial media. Sehingga dunia digital menuntut seluruh masyarakat untuk dapat mengakses, mengkonsumsi teknologi digital agar dapat terus mengikuti perkembangan sosial dan informasi.

PT Indosat Ooredoo Tbk adalah suatu perusahaan penyedia jasa telekomunikasi dan jaringan telekomunikasi di Indonesia. Perusahaan ini manawarkan saluran komunikasi untuk pengguna telepon genggam dan smart phone. PT Indosat Ooredoo di dirikan pada tahun 1967 dan $65 \%$ saham Indosat dimiliki oleh Qatar dimana kata Ooredoo adalah kendali saham terbesar di Timur Tengah, Afrika, 
Asia Tenggara yang dimiliki

oleh Qatar, sehingga Indosat resmi berganti nama tahun 2015 menjadi PT Indosat Ooredoo yang dipimpin oleh Joy Wahjudi selaku CEO atau Presiden Direktur PT Indosat Ooredoo.

Produk yang dihasilkan yaitu IM3 Ooredoo sebagi saluran komunikasi via suara untuk telepon tetap, Indosat Ooredoo juga menyediakan layanan multimedia, internet dan komunikasi data. Layanan digital yang dimiliki Indosat Ooredoo pra bayar, pasca bayar, data rollover, paypro, myIM3.

Aplikasi media internet Indosat Ooredoo adalah myim3, kegunaan dari myim3 ini adalah dapat mengcek pulsa, tagihan, pembelian data dan bonus. Dengan ini para pengguna setia Indosat Ooredoo sangatlah mudah untuk mengakses semua kebutuhan hanya dengan menggunakan aplikasi saja tampa harus ke outlet Indosat. Fitur yang dimiliki aplikasi myim3, informasi tagihan, informasi kartu SIM, jangkauan jaringan, lokasi outlet, store online booking. Ditengah kesibukan pelanggan Indosat Ooredoo, tidak sempat membayar tagihan, membeli pulsa ke outlet, myim3 adalah cara mudah untuk menyelesaikannya sehingga mengurangi aktifitas kesibukan para pelanggan setia Indosat Ooredoo. Pengguna aplikasi myim3 berkisar kurang lebih 5 juta orang, data diperoleh melalui google play store.

Salah satu program Indosat Ooredoo juga memposting iklan, kuis berhadiah, perlombaan kreatifitas, dan kompetisi kompetisi yang bersifat media sosial. Sebagai bentuk pelayanan bagi masyarakat yang terus ikut aktif dalam memperhatikan program program media sosial yang dibuat oleh Indosat Ooredoo. Karena visi Indosat Ooredoo adalah Menjadi Perusahaan Telekomunikasi Digital Terdepan di Indonesia. Misi Indosat Ooredoo layanan dan produk yang membebaskan, jaringan data yang unggul, memperlakukan sebagai sahabat, transformasi digital.

Bicara soal konsumen Indosat Ooredoo di masyarakat dalam menyambut dunia digital ini sangatlah baik, terutama dikalangan mahasiswa, dimana mahasiswa adalah bagian dari masyarakat yang aktif dalam mengkonsusmsi 
teknologi digital, baik dari segi

bisnis, meraih informasi, atau melakukan kreatifitas di media sosial.

Mahasiswa juga sudah banyak yang terjun dalam dunia bisnis dengan menggunakan digital marketing, dan banyak pula universitas yang mengadakan seminar untuk menjadi pembisnis digital marketing yang hebat. Mahasiwa yang memanfaatkan peluang bisnis seperti yang dimana masyarakat sudah banyak belanja berbagai kebutuhan hanya menggunakan gadget. Seperti alat kosmetik, fasion, jual beli alat - alat bekas, bahkan makanan.

Bagaimana tidak mahasiswa banyak yang terjun di dunia bisnis online, untuk dapat joint dalam bisnis tersebut hanya bermodalkan kuota internet, gadget, foto, sosial media, dan followers tentunya. Tanpa harus sewa toko, modal besar, dan rutinitas penjualan. Alasan bagi konsumen online, harga lebih murah, tidak perlu mengeluarkan ongkos keluar rumah, hemat waktu, dan hemat tenaga.

Sebagai pengguna digital marketing mengetahui prilaku konsumen adalah salah satu yang harus diketahui. Konsumen akan memperhatikan merek produk yang akan dibeli, dengan beberapa pertimbangan melihat harga kualitas barang dan perbandingan biaya antara pembelian online atau offline. Faktor kelas sosial juga termasuk dalam prilaku pembeli online, karena paradikma yang terjadi di masyarakat, produk yang bersifat online dipandang berkualitas, walaupun sedikit mahal, sehingga pembeli kelas menengah keatas lebih meletakkan kepercayaan dengan pembelian online. Kelompok sosial juga mendorong masyarakat dalam mengkonsumsi produk - produk online terutama dikalangan mahasiswa, karena mahasiswa cendrung suka menunjukan exsistensinya dalam mengkonsumsi suatu produk.

Perilaku pembeli online sangat beragam, ada juga yang mendahulukan kebutuhan serta hemat biaya, tampa harus memperhatikan merek produk tetapi sesuai dengan apa yang di butuhkan. Begitu juga dengan konsumen yang penuh dengan kesibukan, tampa harus menyediakan waktu untuk ke 
mall cukup pesan melalui gadget langsung diantar sampai kerumah, ini juga menjadi tolak ukur bagi konsumen.

$$
\text { Semakin meningkatnya }
$$
pengguna teknologi digital, semakin meningkat pula konsumen pembeli online. Jumlah pembeli online melalui e-commerse di Indonesia mencapai 24,7 juta orang dengan jumlah mengakses internet 132,7 juta orang berdasarkan data Waresocial 2017. Dengan jumlah pembeli online yang mencapai 24,7 juta orang adalah nominal yang besar, jumlah ini akan terus meningkat seiring dengan meningkatnya pengguna media sosial, jika tidak di seimbangi dengan ilmu pengetahuan makanya masyarakat Indonesia akan hanyut dalam dunia digital yang cendrung melakukan aktifitas dengan praktis dan mudah.

Strategi dalam suatu dunia bisnis atau usaha sangatlah di butuhkan untuk pencapaian visi dan misi yang sudah di terapkan oleh perusahaan, maupun untuk pencapaian sasaran atau tujuan, baik tujuan jangka pendek maupun tujuan jangka panjang.
Barry dalam Tripomo (2005) menyatakan bahwa Strategi adalah rencana tentang apa yang ingin dicapai atau hendak menjadi apa suatu organisasi di masa depan (arah) dan bagaimana cara mencapai keadaan yang diinginkan tersebut (rute). Strategi merupakan hal penting bagi kelangsungan hidup dari suatu perusahan untuk mencapai sasaran atau tujuan perusahaan yang efektif dan efisien, perusahaan harus bisa menghadapi setiap masalahmasalah atau hambatan yang datang dari dalam perusahaan maupun dari luar perusahaan. Strategi merupakan alat untuk mencapai tujuan, dalam pengembangannya konsep mengenai strategi harus terus memiliki perkembangan dan setiap orang mempunyai pendapat atau definisi yang berbeda mengenai strategi.

Terkait dengan pemasaran, Hermawan (2012) mengatakan pemasaran adalah sesuatu yang meliputi suatu sistem yang berhubungan dengan tujuan untuk merencanakan dan menentukan harga sampai dengan mempromosikan dan mendistribusikan barang dan jasa yang memuaskan kebutuhan pembeli 
aktual maupun potensial. Kotler (2008) menjelaskan bahwa pemasaran adalah membuat penjualan tidak diperlukan lagi. Penjualan dan iklan hanyalah bagian dari bauran pemasaran yang lebih besar seperangkat sarana pemasaran yang bekerjasama untuk memuaskan kebutuhan pelanggan dan menciptakan hubungan dengan pelanggan. Disebagian besar masyarakat, pemasaran sering diartikan sebagai proses penjualan barang dan jasa, tetapi apabila dilihat lebih mendalam pengertian pemasaran mempunyai aspek yang lebih luas dari pada pengertian tersebut.

\section{Metode Penelitian}

Penelitian ini dilakukan melalui pendekatan kualitatif. Pendekatan kualitatif menurut Kriyantono (2012) dapat berupa kata-kata, kalimat-kalimat atau narasi-narasi, baik yang diperoleh dari wawancara mendalam maupun observasi. Hal demikian senada dengan yang disampaikan Moleong (2007) yang mengatakan bahwa deskriptif kualitatif adalah sebagai prosedur penelitian yang menghasilkan data deskriptif berupa kata-kata tertulis dan lisan dari orang-orang dan perilaku yang dapat diamati.

\section{Hasil Penelitian dan Pembahasan}

Strategi adalah rencana tentang apa yang ingin dicapai atau ingin seperti apa organisasi tersebut di masa depan dan bagaimana cara mencapaian keadaan yang diinginkan tersebut. Strategi merupakan hal penting bagi kelangsungan hidup dari suatu perusahan untuk mencapai sasaran atau tujuan perusahaan yang efektif dan efisien, perusahaan harus bisa menghadapi setiap masalahmasalah atau hambatan yang datang dari dalam perusahaan maupun dari luar perusahaan.

Pada era digital saat ini banyak perusahaan yang beralih dari sistem konvesional ke sistem digital, dimana promosi dan perkenalan produk banyak diiklankan melalui media sosial. Media online merupakan media yang menggunakan internet yang berbasis teknologi, berkarakter fleksibel, berpotensi interaktif dan dapat berfungsi secara privat maupun secara publik. Media online juga 
bukan hanya sebagai media untuk berbagi informasi, tetapi juga sebagai media orang - orang berkreasi, sudah banyak yang lahir dan berpenghasilan melalui media sosial, baik bentuk penyedia promosi, penyedia fotograpy, penyedia hiburan - hiburan seperti vidio lucu ataupun komik - komik lucu. Hal ini membuktikan bahwa dunia media sosial sangat - sangat berpengaruh pada kehidupan keseharian, terutama sebagai media pemasaran.

Pemasaran adalah sesuatu yang meliputi suatu sistem yang berhubungan dengan tujuan untuk merencanakan dan menentukan harga sampai dengan mempromosikan dan mendistribusikan barang dan jasa yang memuaskan kebutuhan pembeli aktual maupun potensial Hermawan (2012:33). Dalam pemasaran terdapat proses interaksi antara penjual dengan pembeli, pertukaran informasi baik mengenai barang yang di jual maupun informasi lain yang dibutuhkan oleh pelanggan. Soemanagara (2006:4-5) mendefenisikan komunikasi pemasaran sebagai proses pertukaran informasi yang dilakukan secara persuasif sehingga proses pemasaran dapat berjalan effektif dan efesien. Komunikasi pemasaran juga merupakan bentuk komunikasi yang ditujukan untuk memperkuat strategi pemasaran guna maraih segmentasi yang luas.

Strategi digital marketing adalah suatu perencanaan pemasaran produk melalui media digital dengan kegiatan marketing termasuk branding yang menggunakan berbagai media berbasis web seperti blog, website,e-mail, adwords, ataupun jejaring sosial lainnya. Defenisi lain mengemukakan bahwa media online merupakan digitalisasi yang mana sebuah konsep pemahaman dari perkembangan zaman mengenai teknologi dan sains, dari semua yang bersifat manual menjadi otomatis.

Strategi digital marketing melalui media sosial sangat berpengaruh dengan membangun kepercayaan, karena media sosial mengijinkan untuk menampilkan segala secara sesuatu tentang Indosat Ooredoo ataupun tentang bisnis Indosat Ooredoo sehingga dapat dilihat secara nyata dan transparan, karena dengan adanya keterbukaan 
dan keaslian ini membuat komunitas dan konsumen merasa yakin dan aman untuk membangun kepercayaan pada Indosat Ooredoo, hadir terus menerus dalam komunitas online, membuat Indosat terlibat akrab dengan pelanggannya dan keakraban itu menghasilkan kepercayaan. Keeprcayaan dan kredibilitas tentu saja merupakan kunci utama untuk melakukan penjualan dan mengantarkan pada konsumen jangka panjang.

Strategi digital marketing yang dilakukan PT. Indosat Ooredoo Medan dalam mempromosikan produknya salah satunya dengan memposting informasi terbaru ataupun memposting hal - hal yang membuat para pelanggan untuk tertarik dalam mengikuti kegiatan akun media sosial tersebut. pada zaman era digital ini bahwa rata rata para pengguna gadget pasti mengkonsumsi media sosial, sehingga para pengguna media sosial tersebut mengetahui sejauh mana Indosat dalam mempromosikan produknya.

Media sosial yang dipakai oleh Indosat Ooredoo salah satunya adalah instagram dengan alamat akun "kedanim3", akun inilah yang digunakan marketing Indosat sebagai media untuk memposting informasi terbaru maupun kuis - kuis dan kompetisi untuk pengikut akun tersebut. Hasil penelitian menemukan bahwa dengan adanya informasi terbaru dari produk tersebut menandakan bahwa produk tersebut ingin pelanggannya update tentang info terbaru dari produk itu, sehingga dapat berpengaruh kepada kepercayaan pelanggan. Tanpa informasi terbaru yang disampaikan kepada pelanggan maka akan sulit untuk mendapatkan kepercayaan pelanggan.

Akun instagram media sosial Indosat Ooredoo juga sering digunakan sebagai media kompetisi untuk para pengikut akun tersebut dan pemenang dalam kompetisi itu juga diberikan reward langsung oleh pihak Indosat Ooredoo sebagai bentuk apresiasi kepada peserta kompetisi tersebut. Indosat Ooredoo juga memiliki aplikasi tersendiri demi untuk mempermudah pelanggannya mengakses paket nelfon dan paket internet bagi para pengguna kartu perdana Indosat. Paket nelfon yang ditawarkan 
Indosat juga sangat murah dan terjangkau, begitu juga paket Internet Indosat. Hasil penelitian juga menemukan harapan dari masyarakat terkait kualitas jaringan dimana belum semua daerah di kota Medan di dominasi jaringan Indosat.

Terkait strategi digital marketing PT. Indosat Ooredoo dalam meningkatkan kepercayaan pelanggan sudah terbilang baik, hasil dari penelitian ini mengemukakan bahwa digital marketing sangat berpengaruh pada kepercayaan pelanggan karena dilihat dari postingan yang menarik, kompetisi kompetisi berhadiah, sehingga para pelanggan menaruh kepercayaan pada Indosat. Fasilitas aplikasi Indosat yaitu myim3 juga sangat membantu dan mempermudah dalam mengakses paket - paket yang ditawarkan. Fasilitas nelfon dan internet yang disediakan Indosat juga sangat membantu dalam kebutuhan komunikasi sehari - hari.

Media online juga menjadi salah satu penungjang meningkatnya citra dan penjualan pada PT. Indosat Ooredoo seperti yang dikatakan oleh salah satu marketing Indosat bapak Indra sukmana, peningkatan penjualan menjadi salah satu arti yang berkaitan kuat dengan kepercayaan pelanggan, perusahaan - perusahaan lain juga masih sangat antusias untuk bekerja sama dengan Indosat baik parusahaan digital seperti perusahaan smart phone mau pun perusahaan yang bergerak dibidang pendidikan seperti universitas ataupun sekolah, hal ini menandakan bahwa citra perusahaan Indosat masih dipandang baik oleh para masyarakat, dan percaya bahwa Indosat dapat menjadi patner yang baik dalam mengembangkan bisnis yang dibangun oleh prusahaan yang bekerja sama dengan Indosat.

\section{Penutup}

$$
\begin{gathered}
\text { Strategi digital marketing } \\
\text { yang dilakukan Indosat Ooredoo }
\end{gathered}
$$
Medan dalam meningkatkan kepercayaan pelanggan terbilang baik, dilihat dari hasil tanggapan para mahasiswa Dharmawangsa selaku narasumber pada penelitian ini banyak mengatakan bahwa sistem strategi digital marketing Indosat Ooredoo Medan pada media sosial sangat berpengaruh karena pengguna media sosial yang sangat banyak dan menyaksikan postingan - postingan 
ataupun kegiatan kompetisi yang dibuat oleh Indosat Ooredoo Medan tersebut menarik banyak peserta untuk ikut dalam kompetisi tersebut, danreward yang diberikan secara langsung oleh Indosat sehingga dapat menarik perhatian para pengguna media sosial untuk berpartisipasi pada kompetisi tersebut, sehingga menghasilkan konsumen baru dari yang tidak pengguna Indosat menjadi pengguna Indosat.

$$
\text { Indosat Ooredoo terus }
$$
berupaya memberikan yang terbaik dengan memudahkan pelanggannya mengakses kebutuhan pengguna kartu perdana Indosat Ooredoo, banyak narasumber yang mengatakan bahwa dengan adanya aplikasi myim3 sebagai salah satu strategi digital marketing Indosat Ooredoo dapat mempermudah pelanggannya, karena hanya dengan satu aplikasi saja dapat mengetahui informasi terbaru tentang Indosat Oordoo, dan hanya dengan satu aplikasi saja dapat membeli pulsa dan paket nelfon atau internet tanpa harus keluar rumah untuk mendapatkannya. Hal ini juga menjadi salah satu strategi digital marketing Indosat untuk bagaimana mempertahankan dan meningkatkan kepercayaan para pelanggannya.

Paket nelfon murah yang disediakan Indosat Ooredoo juga sangat sesuai dengan kebutuhan masyarakat, terutama kaum muda. Seperti yang peneliti lihat, para narasumber banyak mengatakan bahwa hanya Indosat yang sampai sekarang masih konsisten menyediakan paket nelfon murah. Hal ini dapat peneliti simpulkan bahwa paket nelfon murah yang disediakan oleh Indosat sangat diterima oleh masyarakat. Dengan cara Indosat memasarkan lewat media sosial, dan memposting para pengguna kartu perdana Indosat yang sudah membuktikan murahnya Indosat sehingga menarik orang lain untuk mencobanya. Strategi Indosat dapat dikatakan berhasil karena dapat meraih kepercayaan pelanggan yang sebelumnya tidak menggunakan kartu perdana Indosat.

\section{Daftar Pustaka}
Hermawan Agus. 2012. Komunikasi Pemasaran. Malang. Erlangga.

Kotler Philip. Armstrong. Garry. 2008.

Prinsip-prinsip 
Pemasaran, Jakarta : Jilid 1, Erlangga.

Kriyanto, Rachmat. 2012. Teknik Praktik Riset Komunikasi. Jakarta: Prenada Media.

Moleong J.L 2007. Metodologi penelitiankualitatif, Bndung: Rosda.

Sanjaya. Ridwan dan Josua Tarigan, 2009. Creative Digital Marketing. Jakarta: PT Elex Media Komputindo.
Soemanagara, Dermawan.. 2006. Marketing communicationteknik dan strategi. Jakarta: PT. Buana ilmupopuler. kelompok gramedia.

Susanto J dan Revelim. 2016. Digital Marketing In Action. Jakarta. PT. Pengembangan lintas pengetahuan

Tripomo, Tedjo . 2005. Manajemen Strategi. Bandung :Rekayasa Sains. 